\title{
Situation aspectual properties of creation/consumption predicates
}

\author{
Éva Kardos \\ University of Debrecen \\ kardoseva@unideb.hu
}

\begin{abstract}
This paper is concerned with the situation aspectual properties of creation and consumption verbs. More specifically, it aims to explore how telic interpretations arise in this verbal domain. The analysis which is couched in a scalar semantic framework will focus on how created/consumed themes contribute telicity given the unique, verb-mediated relationship that obtains between these themes and the scales of creation/consumption verbs. Although it is Hungarian verbs that constitute the main data set of this study, examples from English and some other languages will also be discussed for crosslinguistic comparison.
\end{abstract}

Keywords: consumption verbs; creation verbs; scalar semantics; situation aspect; telic

\section{Introduction}

Creation/consumption verbs like English write, build, eat, and drink can be described as expressing events progressing in an incremental fashion as the referent of their theme comes into being or disappears. This incrementality is reflected in the fact that with these verbs there is a precisely definable correspondence between parts of the event described by the verb and parts of the theme undergoing a change in the course of the event. This correspondence, which has been extensively discussed in the literature on aspectology (cf. Verkuyl 1972; 1993; Mourelatos 1978; 1981; Bach $1981 ; 1986$; Krifka $1989 ; 1992 ; 1998)$, can be characterized as follows: a theme with quantized reference contributes to a bounded/telic situation, as in (1), whereas a cumulative theme results in unboundedness/atelicity, as in $(2){ }^{1}$

(1) a. John built a house in a year $/{ }^{? ?}$ for a year.

b. Dave drank a beer in half an hour $/$ ?? for half an hour.

${ }^{1}$ In this work I use boundedness and telicity (as well as unboundedness and atelicity) interchangeably. For a different view, see Depreatere (1995). 
(2) a. John built houses for a year $/ *^{\text {in }}$ a year.

b. Dave drank beer for half an hour $/ *^{*}$ in half an hour. ${ }^{2}$

As evidenced by the compatibility of the in-time adverbial and unacceptability of the for-type adverbial, the sentences containing the verb phrases build a house and drink a beer receive a telic interpretation in (1a) and (1b). This is due to the fact that the themes a house and a beer have quantized reference, i.e., no proper subpart of a house or a beer is in the denotation of the DPs a house and a beer. In a similar vein, no proper subpart of the events expressed by build a house and drink a beer can also be characterized by the same verb phrases. By contrast, the event descriptions associated with $(2 \mathrm{a})$ and $(2 \mathrm{~b})$ are atelic due to the fact that the bare themes houses and beer have cumulative reference. If two things can be described as houses or beer, their sum can also be described as houses or beer. Likewise, if two events are in the denotation of build houses and drink beer, their sum is also in the denotation of the same verb phrases.

Nevertheless, the above correlation between the quantization properties of the theme and the temporal structure of the event described by the verb does not always hold. In certain contexts it is possible to get an atelic reading of a sentence containing spatially bounded objects. This is what the examples in (3) illustrate.

(3) a. I ate the soup for two days, and froze several meal-sized containers for future meals.

(http://sistersosf.org/savory-sacred-soup)

a.' I ate the soup in two days.

b. John built a Lego tower in three hours/for three hours. (Smollett 2005, 50, (18))

In (3) both the soup and a Lego tower have quantized reference, and yet an atelic reading, in addition to a telic reading, is available, as shown by the temporal adverbial test (see also Hay et al. 1999; Kennedy \& Levin 2008, among others). This kind of aspectual duality has also been discussed with respect to other verb classes in English, e.g., activities like

${ }^{2}$ It is well known that in-adverbials are generally compatible with telic predicates and incompatible with atelic predicates and the opposite is true of for-adverbials (on the relevant interpretation). However, as pointed out by Beavers (2012, 26), contextual factors may allow native speakers to get a partitive interpretation of examples like (1a) and (1b), which is why I indicate the unacceptability of the for-adverbials with built a house and drank a beer with two question marks instead of an asterisk. For some reason, this kind of coercion is more difficult with $i n$-adverbials in the environment of atelic predicates and thus I use an asterisk in $(2 \mathrm{a})$ and $(2 \mathrm{~b})$ to indicate the unacceptability of the in-adverbials with predicates like built houses and drank beer. 
run, achievements like arrive, degree achievements like warm and surface contact verbs like wipe. For more on this, see, for example, Dowty (1979); Moens \& Steedman (1988); Hay et al. (1999), and Levin \& Sells (2009). ${ }^{3}$

Furthermore, it is also worth noting that some verbal constructions containing creation/consumption verbs are associated with invariably atelic event descriptions, as in (4).

(4) a. Sam ate at the soup for ten minutes/*in ten minutes.

b. Sam wrote on his dissertation for an hour $/ *^{*}$ in an hour.

Contrary to what we saw in the case of eat the soup in (3), the verb phrases ate at the soup and wrote on his dissertation in (4), which exemplify the conative construction in English, are invariably atelic, as shown by their incompatibility with the adverbials in ten minutes and in an hour, respectively, in spite of the theme's having quantized reference.

A similar picture emerges in Hungarian when it comes to base verbs such as eszik 'eat', iszik 'drink', ir 'write', épit 'build', rajzol 'draw', fest 'paint', tervez 'design', and süt 'bake'. First, the same correlation can be perceived between the referential properties of the incremental theme (Dowty 1991) and the (a)telicity of the verbal predicate as in English, as is apparent from (5) and (6).

(5) a. János tíz perc alatt evett egy almá-t.

J.NOM ten minute under ate an apple-ACC ${ }^{4}$

'János ate an apple in ten minutes.'

b. János tíz perc-ig/*tíz perc alatt almá-t/almák-at evett.

J.NOM ten minute-for/ten minute under apple-ACC/apples-ACC ate

'János ate apples for ten minutes.'

(6) a. Péter egy év alatt épített egy ház-at.

P.NOM a year under built a house-ACC

'Péter built a house in a year.'

b. Péter egy év-ig/*egy év alatt házak-at épített.

P.NOM a year-for/a year under houses-ACC built

'Péter built houses for a year.'

${ }^{3}$ Rothstein (2006) observes that mood can also prevent quantized themes from having a measuring out function in the sentence.

${ }^{4}$ As will be clear from the glosses of the examples in the paper, the Hungarian indefinite article is egy, whereas the definite article has two instantiations, $a$ or $a z$. 
In (5a) and (6a), the quantized themes egy almát 'an apple' and egy házat 'a house' are responsible for a telic reading, whereas bare themes like almát 'apple', almákat 'apples' and házakat 'houses', which have cumulative reference (Maleczki 2008), yield atelicity, as diagnosed by the temporal adverbial test. Crucially, atelic readings are also easily available without any contextual support with themes having quantized reference, as in (7).

(7) a. János tíz perc-ig evett egy almá-t.

J.NOM ten minute-for ate an apple-ACC

lit. 'János ate an apple for ten minutes.'

b. Péter egy év-ig épített egy ház-at.

P.NOM a year-for built a house-ACC

lit. 'Péter built a house for a year.'

Furthermore, there are signs of invariability in Hungarian as well, as shown by the examples in (8) from Kardos (2016).

(8) a. Kati tíz perc-ig/*tíz perc alatt esze-get-ett egy almá-t.

K.NOM ten minute-for/ten minute under eat-FREQ-PAST an apple-ACC

'Kati spent ten minutes eating tiny bites from an apple.' (Kardos 2016, 29, (68a))

b. Kati tíz perc alatt/*tíz perc-ig meg-esze-get-ett egy almá-t.

K.NOM ten minute under/five minute-for PRT-eat-FREQ-PAST an apple-ACC

'Kati ate an apple in small bites in ten minutes.'

(ibid., 30, (70a))

The example in (8a) illustrates that the verb phrase eszegetett egy almát 'eat small amounts of food by taking small bites', which contains the frequentative morpheme - get, is atelic regardless of the quantized nature of the theme, while (8b) shows that once the particle meg is attached to the verb, an invariably telic reading arises. ${ }^{5}$

Similarly to Hungarian particles like meg, the English particle up also leads to strict telicity, as in (9), in the environment of themes with quantized reference. ${ }^{6}$

(9) a. John ate up an apple in five minutes $/{ }^{*}$ for five minutes.

b. John built up a house in a year $/{ }^{*}$ for a year.

${ }^{5}$ As a reviewer points out, it is not only morphologically derived verbs like eszeget 'eat small amounts of food by taking small bites' that can receive a strictly atelic interpretation in Hungarian, but base verbs like majszol 'nibble' can also be invariably atelic.

${ }^{6}$ For more on the telicizing role of English particles like up in eat up, see Brinton (1985). 
However, an important difference between the two languages also arises when it comes to particle verbs. Whereas in English themes with quantized or cumulative reference can appear with a particle verb, it is only themes with quantized reference that can occur with particle verbs in Hungarian. This is illustrated with English eat and Hungarian eszik 'eat' in (10).

(10) a. John ate up apples.

b. János meg-evett *almák-at/egy/három almá-t.

J.NOM PRT-ate apples-ACC/a/three apple-ACC

'János ate (up) three apples.'

While in English the string eat up apples is possible and describes a series of bounded events, in Hungarian strings like ${ }^{*}$ megevett almákat, which consists of a particle verb and a theme with cumulative reference, are ungrammatical. Grammaticality obtains only in the presence of a theme whose quantity is specified, as in the case of egy almát 'an apple' or három almát 'three apples'.

Another interesting property of Hungarian particles is that they are obligatory with some verbal predicates. Achievements like * (el)tör 'break' and *(meg)hal 'die' and degree achievements like *(ki)ürít 'empty' and *(ki)egyenesit 'straighten' show this property, as pointed out by Dékány (2008), É. Kiss (2008b) and Kardos (2012; 2016), among others.

(11) a. János *(el)-tört egy tányér-t.

J.NOM (PRT)-broke a plate-ACC

'János broke a plate.'

b. János *(meg)-halt.

J.NOM (PRT)-died

'János died.'

c. János *(ki)-ürített egy doboz-t.

J.NOM (PRT)-emptied a box-ACC

'János emptied a box.'

d. János *(ki)-egyenesített egy kötel-et.

J.NOM (PRT)-emptied a rope-ACC

'János straightened a rope.'

In this paper, which is a significantly revised version of the analysis given in Kardos (2012; 2016), I would like to address the obligatory nature of particles like $e l$, meg and $k i$ with certain verbs in Hungarian and I also explore how telic interpretations arise in the class of creation/consumption verbs. I aim to show how these verbs, their themes and verbal particles like 
meg contribute to the aspectual interpretation of complex verbal expressions like megeszik egy almát 'eat (up) an apple'. The obligatory nature of telicizing particles will be shown to follow from the Principle of Telicity Marking, a form-to-meaning principle in Hungarian, proposed in Kardos (2012; 2016), according to which telicity must be overtly marked by an event-bounding element. I will also assume based on Kardos (2012; 2016) that verbal particles like those in (10b) and (11) encode an event-maximalizing operator $M A X_{E}$, which is responsible for the semantic constraints that particles impose on themes and the strictly telic intepretations associated with these verb phrases. In the analysis of the aspectual role of the themes of creation/consumption verbs, which will be couched in the scalar semantic framework of Beavers (2012), I claim that given the unique, verb-mediated relationship between the scales and the theme arguments of verbs like eszik 'eat', whereby crucial properties of the scale are directly determined by the theme, the (a)telicity of the event descriptions follow.

The structure of the paper is as follows: in section 2 I present some well-known properties of verbal particles and creation/consumption verbs based on previous analyses. In section 3 I discuss some theoretical assumptions underlying the analysis of the aspectual effect of the internal argument of creation/consumption verbs and I also address how verbal particles and resultative expressions contribute to telicity in Hungarian. In section $4 \mathrm{I}$ provide an analysis of the scalar structure associated with creation/consumption predicates and in section 5 I point out some consequences of the analysis with respect to Hungarian. Section 6 concludes the paper.

\section{Previous literature}

The aspectual structure of creation/consumption verbs has long been an important issue in the literature on aspectology. Various analyses have been proposed for the delimiting role of themes in examples like (1a) and (1b) and the non-delimiting nature of themes in examples like (2a) and (2b), including Verkuyl's (1972; 1993) Plus-principle, Tenny's (1994) Measuring-Out Constraint, and Krifka's $(1989 ; 1992 ; 1998)$ highly influential homomorphism-based account. Aspectual duality in the case of verb phrases like eat the soup has received less attention in the literature than in the case of degree achievements and surface contact verbs. The few works that did address this issue include Hay et al. (1999) and Smollett (2005), who argue that variability in the aspectual interpretation of eattype expressions is possible because telicity with these expressions arises 
via implicatures and thus can be cancelled. ${ }^{7}$ Also, de Swart (1998) analyses variability phenomena as aspectual coercion. As for the absence of aspectual duality, Beavers (2012), for example, explains the obligatory atelicity of data like (4a) and (4b) by analysing the verbal predicates in these examples as being involved in double incrementality, an idea that will be further discussed and adopted in subsequent sections of this paper.

Where Hungarian is concerned, that the internal arguments of creation/consumption verbs like eszik 'eat', iszik 'drink', and süt 'bake' can serve as delimiters has been known for linguists working on this language (cf. Wacha 1978; Kiefer 1992; 2006; Maleczki 1995; 2008; É. Kiss 2005; 2008b; Csirmaz 2008b; Piñón 2008, among others). Particles have traditionally been analyzed as perfectivizing elements (Kiefer 1992; Piñón 1995; Kiefer \& Ladányi 2000; É. Kiss 2002; Alberti 2004). More recently, however, scholars like É. Kiss (2005; 2008b), Csirmaz (2008c), and Kardos $(2012 ; 2016)$ took issue with the idea that verbal particles directly influence grammatical/viewpoint aspect (Smith 1991) by virtue of having a direct perfectivizing role in the sentence and argued for their direct telicizing function. Section 3.3 will reflect on how telicity obtains in the presence of particles. ${ }^{8}$

${ }^{7}$ For more on cancelability in various languages, see Travis (2010).

${ }^{8}$ I follow Csirmaz (2008c) in assuming that viewpoint aspect and situation aspect are distinct, albeit related, grammatical categories in Hungarian. As also discussed by Kardos $(2016,7)$, the contrast between the perfective and imperfective (progressive) aspects is encoded in the syntax in a way that, in the case of particle verbs, the particle precedes the verb in perfective sentences and it follows it in imperfective (progressive) ones. This is shown in (i) and (ii):

(i) A macska fel-mászott a fá-ra. the cat.NOM PRT-climbed the tree-to 'The cat climbed up the tree.'

(ii) A macska 'mászott 'fel the cat.NOM climbed PRT the tree-to amikor a kutya kinézett az óljá-ból. when the dog.NOM looked.out the his.doghouse-from 'The cat was climbing up the tree when the dog looked out of his house.' (adapted from Kardos 2016, 7, (13) and (14))

The grammatical aspectual difference between the sentences above is also reflected in the fact that the sentences are associated with different intonation patterns, as shown by the' sign, which indicates primary stress. However, as for situation aspect, the two sentences are similar in that they both contain telic event descriptions. For more on the independence of situation aspect and viewpoint aspect, see Csirmaz (2008c, 113). 
In addition to their telicizing function, particles with some verbs are also known to trigger the Specificity Effect, which is a semantic-pragmatic restriction on the interpretation of internal arguments (see Szabolcsi 1986; É. Kiss 1995; Bende-Farkas 1995; 2002, among others). I illustrate this with the creation verb talál 'find' in (12).

(12) a. János talált egy kulcs-ot.

J.NOM found a key-ACC

'János found a key - János didn’t know about this key before.'

b. János meg-talált egy kulcs-ot.

J.NOM PRT-found an key-ACC

'János found a key that was known to have been lost.'

What is interesting about the examples in (12) is that whereas in (12a) the theme egy kulcsot 'a key' can only be interpreted as a new entity that János did not know about, in (12b) János or someone else from the context knew about a group of missing keys and János found one of those keys. As pointed out by a reviewer, the Specificity Effect is also observable in English. For example, the direct object in write up a report is familiar, similarly to its Hungarian counterpart meg-ír egy jelentést 'PRT-write a report'. ${ }^{9}$

Finally, verbs like eszik 'eat' and iszik 'drink' have also been shown to exhibit the Definitiness Effect (DE) along with verbs of creation like épit 'build' and rajzol 'draw' (cf. Wacha 1978; Szabolcsi 1986; Bende-Farkas 1995; 2002, É. Kiss 1995; Kálmán 1995, Maleczki 1995). Consider (13).

(13) a. Kati evett egy almá-t.

K.NOM ate.INDEF an apple-ACC

'Kate was eating/ate an apple.'

b. Kati ette az almá-t.

K.NOM ate.DEF the apple-ACC

'Kati was eating the apple.'

An important consequence of the DE is that eszik 'eat' requires a non-specific, indefinite theme unless it appears in a progressive sentence, as in

${ }^{9}$ Another reviewer notes that the theme may also be non-specific in the environment of write up in examples like write up an experiment as in John is going to write up an experiment today. This suggests that the Specificity Effect is a property of verb phrases, and not verbs. 
(13b). ${ }^{10}$ That egy almát 'an apple' is non-specific in (13a) is illustrated below in (14a), where the relative pronoun amit 'which' cannot be linked to the theme of the verb evett 'ate'. This example contrasts with (14b), where the expression egy almát 'an apple' appears with the particle verb meg-evett 'PRT-ate' and can serve as an antecedent to amit 'which'. ${ }^{11}$
a. "Kati
evett
egy
almá-t,
ami-t
már
Kati
ate
an
apple-ACC, which-ACC already
régóta
szerettem volna meg-enni.
for.a.long.time I.liked.DEF would PRT-to.eat
'Kati ate an apple, which I had been wanting to eat for a while.'
b. Kati
meg-evett egy almát, ami-t már
Kati
PRT-ate an apple-ACC, which-ACC already szerettem volna meg-enni.
régóta
for.a.long.time I.liked.DEF would PRT-to.eat
'Kati ate an apple, which I had been wanting to eat for a while.'

That ette az almát in (13b) has only a progressive interpretation is illustrated in (15).

(15) Kati ette az almá-t, amikor Péter be-jött a szobá-ba.

Kati ate the apple-ACC, when Péter in-came the room-to

'Kati was eating the apple when Péter came into the room.'

The only reading that the complex sentence in (15) can receive is that Péter came in as Kati was in the middle of the apple-eating event. This shows that the eating event in the first clause is presented from a progressive viewpoint (cf. Csirmaz 2008c, 113).

The example in (13a), on the other hand, has two readings. The test below provides evidence for this:

(16) Kati evett egy almá-t, amikor Péter be-jött a szobá-ba.

Kati ate an apple-ACC, when Péter in-came the room-to

'Kati ate an apple when Péter came into the room.'

'Kati was eating an apple when Péter came into the room.'

On one reading, the eating event precedes Péter's coming into the room, which is a sign of the availability of perfective aspect in the main clause.

${ }^{10}$ For more on the encoding of the perfective and imperfective aspects in these sentences, see Kálmán (1995, 239).

${ }^{11}$ I thank György Rákosi for the examples in (14). 
The second reading that one can assign to this sentence is that Kati was in the middle of eating an apple when Péter came into the room. This diagnoses progressive aspect.

From the perspective of aspectual composition, another crucial property of DE-verbs is that, unlike most verbs in Hungarian (cf. Kardos 2012; 2016), they can be compatible with a telic interpretation in the absence of telicizing particles or resultative/locative expressions on the condition that they appear with a beneficiary participant in the sentence. Compare (17) and (18).

(17) Mari tíz perc-ig vasalt egy ing-et.

M.NOM ten minute-for ironed a shirt-ACC

'Mari was ironing/ironed a shirt for ten minutes.'

(18) a. Mari tíz perc alatt ki-vasalt egy ing-et.

M.NOM ten minute under PRT-ironed a shirt-ACC

'Mari ironed a shirt in ten minutes.'

b. Mari tíz perc alatt simá-ra vasalt egy ing-et.

M.NOM ten minute under even-to ironed a shirt-ACC

'Mari ironed a shirt crease-free in ten minutes.'

c. Mari tíz perc alatt vasalt (magának) egy ing-et.

M.NOM ten minute under ironed for.herself a shirt-ACC

'Mari ironed a shirt for herself in ten minutes.'

The sentences above illustrate that the DE-verb vasal 'iron' can receive a telic reading either in the presence of a particle like $k i$ or a resultative expression like simára 'crease-free' or, in the absence of these elements, the beneficiary magának 'for herself' can also be responsible for telicity. Building on Milsark's (1977) analysis of English there-sentences, Szabolcsi (1986) proposes that Hungarian DE-verbs contain an existential quantifier. Given that existential sentences have been shown to contain a generalized goal argument (in the sense of Gruber 1965), which can be realised as a possessor, a beneficiary, or a location, it can be claimed that DE-verbs contain such a goal argument. Bende-Farkas and Kamp (Bende-Farkas \& Kamp 2001, 97) illustrate this with the verb lö 'shoot', which, as a DEverb, can only mean 'shoot for some purpose/for someone'. Without a goal argument, there is no definiteness effect. Other meanings involving shooting must be expressed with particle verbs like le-lö 'eliminate by shooting' and meg-lö 'wound by shooting'. Informally speaking, telicity concerns the attainment of a goal point in the course of the denoted event, and thus the acquisition of a telic reading is expected. 
In what follows I will further explore these phenomena within the framework of scalar semantics. Although I focus on predicates like eszik egy almát 'eat an apple' and its English counterpart, I will also offer some insights into how various facts of Hungarian particle verb constructions can be accommodated in the analysis.

\section{Theoretical assumptions}

\subsection{The model in a nutshell}

In my analysis, I follow Beavers (2012), ${ }^{12}$ which is an extension of Krifka (1998), in assuming the following: All entities belong to one of three domains, the domain of objects $U_{E}$, the domain of events $U_{E}$, or the domain of connected, directed paths $P_{H}$. The set of objects $U_{E}$, the set of events $U_{E}$, and the set of connected direct paths $P_{H}$ are structured as complete join semilattices without a bottom element. The lattice structures are characterized by the sum operation $\left(\oplus_{P}, \oplus_{E}, \oplus_{H}\right)$, which is commutative, idempotent, and associative. The entities in $U_{E}, U_{H}$, and $P_{H}$ may be related to each other via the part relation $\left(x^{\prime} \leq_{X} x\right)$, the proper part relation $\left(x^{\prime}<_{X} x\right)$ or the overlap relation $\left(x^{\prime} \otimes_{X} x\right)$. Non-overlapping events in $U_{E}$ are ordered by a temporal precedence relation $\left(e^{\prime} \ll_{E} e^{\prime \prime}\right)$ and non-overlapping paths are partially ordered by a spatial precedence relation $\left(x^{\prime} \ll_{H} x^{\prime \prime}\right)$. Also, any two entities $x^{\prime}$ and $x^{\prime \prime}$ in $U_{E}$ and $P_{H}$ may be adjacent $\left(x^{\prime} \infty_{X} x^{\prime \prime}\right)$. The mereological part structures of incremental themes and those of events are related to each other by homomorphisms, which are encoded by the head verb. These homomorphisms ultimately give rise to the structural analogy between nominal and verbal expressions in cases like (1) and (2). On this analysis, a predicate is telic iff for any event it describes it does not describe any non-final subevent of that event (Beavers 2012, 35, (2.23)). See also Krifka (1992, 35).

A crucial ingredient of this analysis is that the aspectual structure of predicates is determined by not one but two incremental themes, the participant that undergoes some kind of change, referred to as the figure, and the path that serves as a spatial trajectory for the event. Consider the examples in (19) from Filip $(1999,100,(33))$.

${ }^{12}$ I refrain from discussing Beavers (2012) in detail in this paper since in section 2.2 of Kardos (2016) I provide an in-depth characterization of this model. 
(19) a. The earthquake shook a book off the shelf in $/{ }^{?}$ for a few seconds.

b. The earthquake shook books off the shelf for $/$ ?? in a few seconds.

c. The earthquake shook a book for/?? in a few seconds.

d. The earthquake shook books for/?? in a few seconds.

The sentences above reveal that a telic interpretation becomes available only in the presence of a theme/figure whose quantity is known and a bounded path, as in (19a). If either of these two conditions fails to hold, atelicity emerges, as in (19b), (19c) and (19d).

Beavers captures double incrementality by proposing that ternary homomorphic relations, which he refers to as figure/path relations (FPRs), obtain between the part structure of events, the part structure of paths, and the part structure of figures. As argued at length in Beavers (2012, 35-44), it follows from the definition of telicity and figure/path relations that in order to determine the boundedness of the event (i.e., the telicity of the predicate), we must know how much of the figure ends up where on the path. More precisely, telicity arises if the figure has quantized reference and the path is bounded.

In addition, this model is also innovative in the sense that it provides a uniform analysis of incremental theme verbs by assuming that they are associated with mereological scalar structures along which change occurs. ${ }^{13}$ Section 3.2 is aimed at providing some insights as to crucial properties of these structures.

\subsection{Scales in the analysis}

In recent years a growing body of research has suggested that dynamic verbs form two natural classes as scalar or nonscalar and that class membership has consequences for aspectual behavior and argument realization (cf. Hay et al. 1999; Kennedy \& McNally 2005; Wechsler 2005; Kennedy \& Levin 2008; Rappaport Hovav 2008; Rappaport Hovav \& Levin 2010; Kennedy 2012, among others). A scale, as encoded by certain verbs, is generally described as an ordered set of degree values for a particular attribute (e.g., volume, temperature, length, width) associated with an event

${ }^{13}$ In previous literature, Tenny (1994), for instance, distinguished between three types of verbs encoding some kind of incrementality, i.e., incremental theme verbs like eat, change-of-state verbs like ripen, and route verbs like walk. Other works including Jackendoff (1996); Hay et al. (1999); Kennedy \& McNally (2005), and Ramchand (2008) have also analyzed different predicates expressing an incremental change under one rubric. 
participant. In light of this, a scalar change - change along a scale - can be defined as follows:

(20) A scalar change is one which involves an ordered set of changes in a particular direction of the values of a single attribute.

(Rappaport Hovav 2008, 17)

Predicates expressing scalar change include warm, cool, ascend, descend, build a house, and eat an apple, whereas non-scalar predicates are illustrated by dance, play, exercise, scrub, and steam (Rappaport Hovav \& Levin 2010). Scalar verbs are further grouped into various subclasses based on the type of scales that they encode. For instance, warm and cool have property scales, ascend and descend have path scales, whereas build a house and eat an apple have volume/extent scales. Scalar verbs can also differ with respect to the complexity of their scale. Verbs like warm and cool are associated with scales having multiple values, whereas verbs like break and die have scales with exactly two degree values, i.e., an initial and a final degree value (Beavers 2008). Verbal predicates on this view are taken to express a transition between these values. For example, break expresses a transition between an initial value of its property scale corresponding to a state of affairs where the entity undergoing change is not broken and a final degree value, which corresponds to a state of affairs where this entity is broken. The type of scale that a predicate is associated with has important consequences for the aspectual interpretation of the predicate. For instance, predicates like break the vase, which encode two-point scales, are inherently telic, whereas predicates of the type warm the soup, which have multi-point scales, are interpreted as atelic or telic. Furthermore, multipoint scales can also differ as to whether they are open-ended or upper closed; the former type of scale is encoded by predicates like warm, which are by default atelic in the presence of a theme with quantized reference (cf. warm the soup), whereas predicates encoding a closed scale are generally assigned a telic interpretation in the presence of quantized objects (cf. straighten the rope). For more on this, see Kennedy \& McNally (2005).

Beavers (2012) states that perhaps all predicates of change are associated with a scale. In earlier work, he provides various pieces of evidence for this claim, including the occurrence of overt scalar expressions in degree achievements and various resultative constructions, and the fact that, in some cases, the aspectual properties of a verb can be tied to the scalar properties associated with the adjective underlying that verb (see also Kennedy \& Levin 2008, 156). ${ }^{14}$ On this view, verbs have an additional argument slot

\footnotetext{
${ }^{14}$ For a detailed discussion of these pieces of evidence, see Beavers (2006, 89-94).
} 
that denotes a scale, where scales are associated with a mereological part structure, just like the event argument and the figure argument. ${ }^{15}$ More precisely, a scale is a directed path $s \in P_{H}$ with the following properties:

(21) a. Each $s \in P_{H}$ represents a specific property.

b. Degrees on $s$ are atomic subparts of $s .{ }^{16}$

c. Precedence relation $\ll_{H}$ orders subparts of $s$.

(Beavers 2012, 53, (2,54))

This reinterpretation of scales makes it possible that dynamic predicates of different types can be analyzed in a uniform manner. Their representation in a Krifka semantics would be as in (22): ${ }^{17}$

(22) a. The liter of wine flowed onto the floor in/? for one minute.

$\lambda e \exists s[$ flow' (wine, $s, e) \wedge G O A L($ floor $, s, e)]$

b. Caesar wiped the table clean in/?? for one minute.

$\lambda e \exists s\left[\right.$ wipe $^{\prime}($ caesar, table, $s, e) \wedge G O A L($ clean, $\left.s, e)\right]$

c. Caesar drank his beer in/? for one minute.

$\lambda e \exists s\left[\operatorname{drink}^{\prime}\right.$ (caesar, beer, $\left.s, e\right) \wedge G O A L(\mathbf{e m p t y}, s, e)$

(adapted from Beavers 2012, 43, (2.38); 53 (2.55a); 57, (2.66a))

The representations above show that all these predicates describe an event $e$ that progresses along some scale $s$. In each case, the verbal predicate provides sufficient information as to the quantity of the referent of the argument undergoing a change and is responsible for the boundedness to the scale, as indicated by the constants floor, clean, and empty, respectively, representing the fixed value of the goal point of the scale. Given that these two conditions are met, telicity arises, as indicated by the temporal adverbial test. Something that is left unspecified is, however, the difference between various predicates when it comes to the relationship between the scalar and the figure arguments. As Beavers $(2012,58)$ notes in his discussion of the aspectual effect of the internal complexity of the theme on the verbal predicate, where he provides further evidence for multiple incrementality, creation/consumption predicates like eat differ from predicates like wipe in that the former are associated with scales that are directly determined by the theme argument. In previous literature, Levin (2010, 14) also points out that the extent scales of predicates like eat an apple

${ }^{15}$ Note that scalar analyses like Hay et al. (1999) and Kennedy \& McNally (2005) do not attribute a mereological part-whole structure to scales. For more on mereological and non-mereological scalar approaches to lexical aspect, see Filip (2012, 735-745).

${ }^{16}$ An atomic entity $x$ has no subparts other than $x$ (cf. Beavers 2012, 48).

${ }^{17}$ Boldface indicates logical constants in the representations. 
are "qualitatively" different from property scales (cf. warm and cool) and path scales (cf. ascend and descend) by virtue of the fact that in the case of eat an apple the theme specifies the scale, whereas in the case of warm, cool, ascend, and descend, the scale is inherent in the meaning of the verb. A more precise characterization of how exactly the theme determines the structure of creation/consumption scales is, however, missing from these analyses. This gap is what I would like to fill in section 4 of this paper. Before that, however, I review how verbal particles telicize verbal predicates in Hungarian.

\subsection{Event maximalization in Hungarian}

In Kardos $(2012 ; 2016)$ I argue that in Hungarian telicity must be overtly marked. This is expressed in the following principle:

(23) Principle of Telicity Marking: Telicity must be overtly marked by event bounders.

In the domain of non-creation/non-consumption verbs, which is the subject of investigation in Kardos (2016), overt telicity marking is typically carried out by verbal particles and resultative/locative expressions in a way that they encode an event-maximalizing operator $M A X_{E}$, which picks out the largest events in the denotation of verb phrases (Filip \& Rothstein 2006; Filip 2008). The definition of $M A X_{E}$ is as follows:

(24) Telicity corresponds to the maximalization operator $M A X_{E}$. It is a monadic operator, such that $M A X_{E}\left(\sum\right) \in \sum$, which maps sets of partially ordered events $\sum$ onto sets of maximal events $M A X_{E}\left(\sum\right) \in \sum$.

(Filip \& Rothstein 2006, 139, (2))

An important novelty of the analysis in Kardos $(2012 ; 2016)$ is that, in accordance with Beavers's (2012) figure-path relations (FPR) model, the events are partially ordered relative to the part structure of the internal argument and the part structure of the scale/path. The event-maximalizing operator applies in the presence of a verb lexicalizing a figure-path relation, a theme whose quantity is known and a bounded path. ${ }^{18}$ This has important interpretive consequences for the verbal predicate. For example, in the presence of an event-maximalizing element, aspectual duality does not emerge. This is shown in (25) with the degree achievement verb melegit 'warm'.

${ }^{18}$ For a detailed discussion of event maximalization, see section 3.2 in Kardos (2016). 
(25) a. Mari 10 perc-ig/*10 perc alatt melegített egy csészé-t. M.NOM 10 minute-for/10 minute under warmed a cup-ACC 'Mari warmed a cup for 10 minutes.'

b. Mari 10 perc alatt/*10 perc-ig fel-melegített egy csészé-t. M.NOM 10 minute under/10 minute-for PRT-warmed a cup-ACC 'Mari warmed a cup in 10 minutes.' $\quad$ (adapted from Kardos 2016, 14-15, (28))

As evidenced by the temporal adverbial test, the sentence containing the base verb melegit 'warm' is interpreted as strictly atelic, whereas the sentence with the particle verb fel-melegit 'PRT-warm' is strictly telic.

Yet another consequence of the event-maximalizing operation and the FPR is that non-specific themes like csészék 'cups', which have cumulative reference, cannot occur in the presence of particle verbs like fel-melegit 'PRT-warm'.

(26) a. *A kukták fel-melegítettek csészék-et. the sous chefs.NOM PRT-warmed cups-ACC

b. A kukták fel-melegítettek egy/három csészé-t. the sous chefs.NOM PRT-warmed a/three cup-ACC 'The sous chefs warmed a specific cup/three cups.' (telic) (Kardos 2016, 19, (31))

As for the semantic effect of verbal prefixes or verbal particles on the incremental theme and the aspectual interpretation of the verbal predicate, there are differences across languages. As shown by Borer (2005), verbal particles in English do not necessarily impose a semantic requirement on themes such that they be specific. Consider (27).

(27) We ate up sandwiches (for hours/all afternoon/*in three hours).

(adapted from Borer 2005, 211, (56a))

Examples like (27) show that English up does not have an event-maximalizing function; it does not necessarily lead to a telic predication. ${ }^{19,20}$

Yet another pattern is observable in Slavic languages like Bulgarian or Upper Silesian, a south-west dialect of Polish. As pointed out by Czardy-

${ }^{19}$ Borer also shows that once the particle shows up after the object, examples like (27) become ungrammatical. For more on this, see Borer (2005, 210-211).

${ }^{20}$ As for other Germanic languages, there are different judgements in the literature regarding the co-occurrence of particle verbs and themes with cumulative reference. Travis $(2010,248)$, for example, provides the following data from Dutch and German, where in each case the particle verb appears with a bare noun and an atelic interpretation arises. 
bon and Fleischhauer (2014), although the incremental theme predication becomes telic if the verb is perfective, the definite article is not required, unlike in Hungarian. This is shown in (28).

(28) a. Łon z-jodPF jabk-o za godzina.

he Z-eat.PAST apple-ACC.SG in hour

'He ate an apple in an hour.'

b. Łon z-jodPF te jabk-o za godzina.

he Z-eat.PAST DEF apple-ACC.SG in hour

'He ate the apple in an hour.'

(Upper Silesian; Czardybon \& Fleischhauer 2014, 389, (25))

By contrast, if the incremental theme is a bare plural or a mass noun, a telic interpretation can only arise in the presence of the definite article. If the definite article is not present in the sentence, it is only a kind reading of the incremental theme that is available.

(29) a. Łon z-jod ${ }_{P F}$ jabk-a.

he Z-eat.PAST apple-ACC.PL

'He ate [some plurality of the kind] apple.'

(i) Elena heeft ?? binnen een jaar/jarenlang brieven afgeschreven

Elena has within a year/years-long letters off-written

'Elena finished writing letters ?? within a year/for years.'

(Dutch; Travis 2010, 248, (9b))

(ii) Ich habe *in zwei Stunden/ ${ }^{?}$ zwei Stunden lang Weinflaschen ausgetrunken

I have in two hours/two hours long wine bottles up-drunk

'I drank up wine bottles *in two hours/?for two hours.'

(German; ibid., (10b))

The Dutch example in (i) and the German example in (ii) show that it is possible for non-specific themes like brieven 'letters' in Dutch and Weinflaschen 'wine bottles' in German to appear in the environment of particle verbs like afgeschreven and ausgetrunken, respectively. However, a reviewer finds the German example odd and the following example is also considered ungrammatical by Fleischhauer and Czardybon (2016), where the German verb aufessen 'eat up' appears with the bare noun Äpfel 'apples':

(iii) *Der Mann hat Äpfel auf-gegessen.

the man has apples AUF-eaten

According to the authors, the example above becomes grammatical once the definite article die appears in the sentence. This datum shows that German is similar to Hungarian in that auf seems to have an event-maximalizing function. 
b. Łon z-jod ${ }_{\mathrm{PF}}$ te jabk-a za godzina.

he Z-eat.PAST DEF apple-ACC.PL in hour

'He ate the apples in an hour.'

Returning back to Hungarian, it is important to note that event maximalization in this language is not only dependent on a verb encoding a figure-path relation, a theme whose quantity is known and a bounded path, but it is also required. This is supported by the facts in (30) and (31).

(30) a. "A kukták melegítettek több, mint három csészé-t. the sous chefs.NOM warmed more than three cup-ACC

b. ?'A munkások szélesítettek több, mint három ut-at. the workers.NOM widened more than three road-ACC

(31) a. A kukták 10 perc alatt/*10 perc-ig fel-melegítettek the sous chefs.NOM 10 minute under/10 minute-for PRT-warmed több, mint három csészé-t. more than three cup-ACC

'The sous chefs warmed more than three cups in 10 minutes.'

b. A munkások 10 év alatt/*10 év-ig autópályá-vá szélesítettek/ the workers.NOM 10 year under/10 year-for freeway-into widened ki-szélesítettek több, mint három ut-at. PRT-widened more than three road-ACC 'The workers widened more than three roads into a freeway in 10 years.'

(Kardos 2016, 21, (38) and (37))

As the examples in (30) show, the base degree verbs melegit 'warm' and szélesit 'widen' are unacceptable in the presence of the quantified themes több, mint három csészét 'more than three cups' and több, mint három utat 'more than three roads'. The event-maximalizing particles fel and ki or the resultative expression autópályává lit. 'into a freeway' appear to be required so that the respective sentences become fully grammatical, as in $(31) \cdot{ }^{21}$

${ }^{21}$ A reviewer points out that once the quantified expression occupies the pre-verbal focus position, the sentence in (30a) becomes fully acceptable, whereas (30b) is only slightly marked. As noted by Kardos $(2012,75)$, this "remedial" effect of focus is also illustrated by the fact that sentences like (26a) can be improved once the bare plural theme occupies the focus position as in A kukták csészéket melegitettek fel 'It was cups that the sous chefs warmed up'. I leave for further research the question of how focus improves the acceptability of these sentences. 
That telicity must be overtly marked via an event-bounding element, e.g., a particle, is supported by the fact that achievements must generally be expressed by particle verbs in Hungarian, as also pointed out by Komlósy (1994), Szili (2001), and É. Kiss (2005; 2008b). The obligatory presence of an event-maximalizing element is also observable in the case of degree achievements associated with an inherent endpoint, such as ki-ürít 'PRT-empty' and ki-egyenesit 'PRT-straighten'. Examples illustrating this are provided in (32) and (33).

(32) a. János *(fel)-robbantott egy ház-at.

J.NOM (PRT)-exploded a house-ACC

'János exploded a house.'

b. Péter *(fel)-ért a hegycsúcs-ra.

P.NOM (PRT)-reached the hilltop-to

'Péter reached the hilltop.'

(33) a. Sára *(ki)-ürített egy doboz-t.

S.NOM (PRT)-emptied a box-ACC

'Sára emptied a box.'

b. Mária *(ki)-egyenesített egy kötel-et.

M.NOM (PRT)-straightened a rope-ACC

'Mária straightened a rope.'

As pointed out at the outset, telicity marking can also be achieved by themes of creation/consumption verbs both in English and Hungarian. ${ }^{22}$ This marking strategy is, however, significantly different from the eventmaximalizing strategy for which Hungarian verbal particles and resultative/locative expressions are responsible. Section 4 is meant to show how created/consumed themes make verb phrases telic.

${ }^{22}$ Pseudo-objects like egyet in tüsszentett egyet 'sneezed once', jót as in jót táncolt a lakodalomban 'had a good dance at the wedding' and nagyot as in nagyot bulizott 'had a great party experience' can also delimit events in Hungarian. However, these elements differ from verbal particles and resultative expressions in that the former do not name a prominent result state at the termination of the denoted event. For more on these delimiters, see Csirmaz (2008a) and Farkas \& Kardos (2018; 2019; in press). 


\section{The scalar structure of creation/consumption predicates}

In this section my goal is to explore how the scalar structure of creation/ consumption predicates is determined by the theme argument. What follows from the analysis is that created/consumed themes with quantized reference impose (upper) bounds on creation/consumption scales and, consequently, the necessary conditions for telicity will be satisfied. Thus a telic interpretation arises even in the absence of particles or resultative expressions, which are directly responsible for telicity in the class of non-creation/ non-consumption predicates in Hungarian. ${ }^{23}$ Conversely, in the presence of themes that have cumulative reference, the goal point of the scale cannot be fully determined, thereby making it impossible for the listener to identify an endpoint to the event, which in turn yields atelicity. For purposes of clarity, in this section, I will mainly, albeit not exclusively, discuss the scalar structure of consumption predicates, which I will illustrate with English examples.

An important intuition behind the analysis is that predicates like eat describe events in the course of which some amount of the referent of the affected argument - but minimally one bite of food - disappears completely and they also encode that the denoted event progresses as the theme undergoes change in an incremental fashion. ${ }^{24}$ These properties suggest that

${ }^{23}$ As will be made clear later in this section, telic creation/consumption predicates actually meet more conditions than is required for telicity by virtue of always supplying specific information as to both the source point and the goal point of their scale and hence also the intial and the final subevents.

${ }^{24}$ Canonical examples to which this description applies are those containing themes that have a complex mereological structure as in eat an apple and drink two beers. In the case of examples like eat a marble or eat a grape, brought to my attention by Marcel den Dikken (p.c.), where the figure is conceptualized as atomic (i.e., undecomposable), the consumption change can be conceived of as a change from an initial state where the referent of the theme is intact to a final state in which the theme has completely disappeared. In other words, verbal predicates like eat a marble and eat a popcorn express momentary events. This is evidenced by the following data:

(i) a. Kate will eat a marble/grape in half an hour.

b. Kate will eat a chicken in half an hour.

The example in (a), which contains an atomic figure, has a single interpretation such that the marble/grape will be consumed once half an hour has passed, whereas the example in (b), which contains a non-atomic figure, is ambiguous. It is either the case that a chicken will be consumed once half an hour has passed or the chickeneating event will last half an hour (cf. Beavers 2012, 51-56). I assume this to be reflected in the scalar structure of these predicates. I propose achievements like eat a marble/grape are associated with a simplex/two-point scale and accomplishments 
verbs like eat are scalar, i.e., they are associated with a scalar argument similarly to degree achievements like warm and cool (Beavers 2012, 57). ${ }^{25}$ However, as hinted in the previous section, predicates like eat also differ from predicates like warm and cool since in the case of the former crucial properties of the scale are directly determined by the internal argument (i.e., the figure), in that the structure of the consumption scale of eat-type predicates reflects how the referent of the figure argument is consumed bite by bite in the course of the event. Conversely, when it comes to examples like warm the soup, no such correspondence can be detected between the part structure of the (property) scale and the part structure of the figure argument, i.e., the soup. In other words, the head verbs of creation/ consumption predicates select their scalar arguments as required by their figure arguments, whereas the head verbs of other dynamic verbs select their scalar arguments independently of their figures.

Following Beavers (2012), I assume that consumption predicates like eat express a four-place relation between a consumption scale $s$, a causer $y$, a figure $x$, and an event $e$ such that $y$ eats $x$ in $e$ that progresses along $s$. Scale $s \in S_{\text {cons }}$ forms a mereological part structure and it is related to the part structure of the figure argument and the part structure of the event argument via ternary figure/path theta relations (see section 3.1). Atomic subparts of a scale $s$ are totally ordered states (e.g., $s_{0}, s_{1}, s_{2}, s_{3}$, etc.), which correspond to states of affairs wherein arbitrary units of the theme have been consumed. For expository purposes, in what follows, I refer to these arbitrary units as bites, which serve to measure how the event denoted by the verbal predicate progresses. It is important to bear in mind that given how mereological structures are built, proper subparts of a scale $s$ are also scales, though the predicate may select only one of these. The properties of the set of consumption scales $S_{\text {cons }}$, which is a set of directed, connected paths, are summarized in (34).

like eat a chicken are associated with a multi-point scale, the structure of which is discussed in detail below.

${ }^{25}$ Caudal and Nicolas (2005) also share the view that verbs such as eat have a scalar structure, contra claims by, for example, Rappaport Hovav (2008), and Rappaport Hovav and Levin (2010), who propose that verbs like eat and drink are not scalar. According to these authors, the volume/extent scale in predicates like eat an apple and drink a beer is lexicalized by the theme. Also, Copley and Harley (2018) side with Malka Rappaport Hovav and Beth Levin in claiming that eat-type verbs express simple properties of events (or "forces" in their terminology) and further propose that the incremental theme DPs of these verbs, which denote entities, are coerced into a measure function, which "ensures homomorphism between the extent of the entity and the progress of the change" (op.cit., 15). This is an idea in line with the analysis given in the present paper. 
(34) a. Atomic elements in $S_{\text {cons }}$ are $s_{i}$, where $i \geq 0$.

b. For any $s, s_{i}, s_{j} \in S_{\text {cons }}$, where $s_{i}$ and $s_{j}$ are atomic, if $s_{i}$ and $s_{j}$ are proper parts of $s, s_{i} \ll s_{j}$ (i.e., $s_{i}$, the state of having consumed as many bites as $i$ is ordered before $s_{j}$, the state of having consumed $j$ bites) iff $i<j$.

To illustrate how themes directly determine scales, I now illustrate visually the relationship between these two entities in Figure 1, where $b_{1}, b_{2}$, etc. indicate the various bites the theme can be partitioned into in a consumption event:

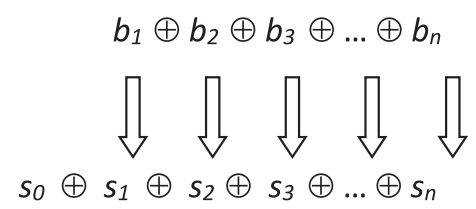

Figure 1: The part structure of the consumption scale as determined by the part structure of the theme

What the figure above demonstrates is that the structure of the consumption scale is maximally determined by the structure of the theme given that atomic subparts of the scale correspond to atomic subparts of the theme. The figure/path relation as encoded by the verb ensures the following structure for the event: The initial subevent corresponds to a state of affairs where not a single bite of the referent of the figure has been consumed, in other words the referent of the theme is available for consumption in its entirety. Subsequent subevents represent states of affairs wherein the first bite, the second bite, the third bite, etc. are consumed. The final subpart of the event is where the figure has disappeared completely. This progression of the event is what is reflected by the scale, which has atomic subparts $s_{0}, s_{1}, s_{2}, s_{3}$ and so on. The verb phrase receives a telic interpretation just in case the goal point on the scale, i.e., $s_{n}$, can be precisely determined. This is ensured if the predicate provides specific information as to the material extent of the theme; i.e., the theme has quantized reference. ${ }^{26}$

${ }^{26}$ It remains to be explored why an atelic interpretation is also available in languages like English and Hungarian with some incremental themes that have quantized reference in the class of creation/consumption predicates (see examples (3) and (7)). What this paper aims to show is how telic interpretations arise in the presence of quantized themes in this verb class. 
An important upshot of this is that, unlike dynamic predicates like warm two plates and cool two plates, telic consumption predicates like eat two pears always determine uniquely the source point of their scale, which is $s_{0}$, and telicity in these cases will always be due to the quantized properties of the theme, which are inherited by the predicate as a whole. In this respect they contrast with predicates like run to the bank and walk to the university, which are not quantized but telic. Notice that in the case of run to the bank, for instance, it is possible for multiple running events to be in the denotation of the predicate given that the initial point to the event is not named. ${ }^{27}$

As for creation predicates I propose that, given that there is a great degree of similarity between how consumption events and creation events unfold (i.e., both types of event advance in an incremental fashion as the theme disappears or comes about), creation scales have a similar structure to that illustrated in Figure 1 with the caveat that creation events progress along the creation scale as the created individual comes about bit by bit. These bits can be thought of as the units of creation $\left(u_{0}, u_{1}, u_{2}, u_{3}\right.$, etc.). That is, subparts of the creation scale are structured according to how subparts of the created theme come about: The initial subpart of the scale, i.e., $s_{0}$ corresponds to a state of affairs where not a single unit of creation has come into existence, $s_{1}$ corresponds to a state of affairs where one unit of creation has come into existence, and so on until the theme reaches the final state of its being created, i.e., $s_{n}$. The final state can be determined, and hence telicity arises, just in case the verb phrase provides information as to the quantity of the theme, as in the case of the predicate built two houses (cf. (1)).

As discussed in von Stechow (2001), an important property of creation verbs is that their objects do not exist before the termination of the events that they describe. Creation verbs are not transparent, but temporally opaque. In this respect, these verbs differ from verbs like break and warm in break a vase and warm a plate, respectively, which also express a change of state of an entity. I believe the scalar structure proposed for verbs of creation is compatible with the fact that creation objects do not

${ }^{27}$ Krifka $(1998,207)$ addresses the difference between the notions 'telic' and 'quantized' as follows: "It is obvious that quantized predicates are telic: If a quantized predicate $X$ applies to some event $e$, then it does not apply to any proper part of $e$, hence the only $e^{\prime}$ such that $X\left(e^{\prime}\right)$ and $e^{\prime} \leq e$ is $e$ itself, which is both an initial and final part of $e$. But not every telic predicate is quantized; quantization is the stricter notion. For example, assume that $X$ is a predicate that applies to all events that have a run time from 3 p.m. to 4 p.m.; $X$ is telic, but not quantized". 
exist during the event time as, for instance, the initial subpart of creation scales corresponds to a state of affairs in which no subpart of the object exists. However, since the present paper focuses on the aspectual effects of created/consumed objects, I will not discuss temporal opacity any further.

This representation of creation/consumption scales is reminiscent of Verkuyl and Zwarts's (1992) path structures, which they assume for verb phrases like walk to the store and eat three apples alike. The assumption of paths in the meaning of such verb phrases is rooted in Jackendoff's work (cf. 1983; 1990) where it is proposed that both walk and eat describe motion events in the course of which some entity $x$ moves along some path $p$. In Verkuyl \& Zwarts (1992) the theme determines the path in a way that the denotation of the theme is partitioned and the cells of this partitioning are mapped to a temporal path, thereby creating a new, spatiotemporal path of pairs of points in space and points in time. For instance, the event of some agent eating three apples as described by eat three apples has three subevents given the cardinality information encoded in three apples. The boundedness of the spatiotemporal path, and thus telicity, here depends on the boundedness of the spatial path.

There are at least two ways in which the analysis of the present paper differs from Verkuyl \& Zwarts (1992). First, as also pointed out in Beavers (2012) and Kardos (2016), an important merit of mereological scalar semantic analyses is that their objective is not only to predict telicity by determining the exact point in space that some entity reaches but also to provide a precise characterization of the internal structure of events by representing how exactly the part structure of the theme and the part structure of the scale are mapped to the part structure of the event. On the present analysis, but unlike on Verkuyl and Zwarts's (1992) analysis, the partitioning of the scale associated with eat apples and the scale associated with eat three apples will be similar given the lexical information encoded in the head verb eat, i.e., in both cases the scalar structure is specified as the apples disappear bite by bite. Another difference between Verkuyl and Zwarts's path structure and the consumption scale proposed in this paper is that the latter but not the former reflects change as described by predicates like eat three apples more precisely by having an initial subpart $\left(s_{0}\right)$ corresponding to a state of affairs in which the theme is available in its entirety and further subparts corresponding to various states of affairs in which the theme appears in different quantities depending on how much of it has been consumed. In other words, as pointed out in footnote 21, the source point is always known in the case of such predicates, unlike in the case of walk to the bank, which is not captured on Verkuyl and Zwarts's analysis. 
One question that remains is how to identify the final subpart of the scale, which is necessary for telic interpretations. I suggest this be achieved through the function $f^{\prime}$ in (35), which serves to pick out the final subpart of consumption scales given that it is known how much of the figure participates in the event. ${ }^{28}$

(35) $f^{\prime}(x)=s_{\#(x)}$ where $\#(x)$ equals the state of affairs where there is complete disappearance of the theme

The idea is that it is this function that allows us to identify the final subpart of the consumption scale when the theme has quantized reference, which in turn satisfies the conditions for telicity to arise. In the case of creation predicates, the output of the function is the state on the scale that corresponds to the theme's coming into existence over the course of the denoted event. This state is identifiable in the presence of themes that have quantized reference. Again, once the quantization/boundedness requirements of the theme and the scale are fulfilled in the predicate, a telic reading becomes available.

With all the above in mind, I propose the following formal representations for the telic and atelic predicates in (36), which contrast with the predicates in (37) in terms of the scalar structure that they are associated with.

(36) a. Peter ate two pears.

$\exists s \exists x \exists e\left[e^{e a t^{\prime}}(\right.$ peter, $\left.x, s, e) \wedge S O U R C E\left(s_{0}, s, e\right) \wedge G O A L\left(f^{\prime}(x), s, e\right) \wedge 2 p e a r s^{\prime}(x)\right]$

b. Peter ate pears.

$\exists s \exists x \exists g \exists e\left[e a t^{\prime}(\right.$ peter, $\left.x, s, e) \wedge G O A L(g, s, e) \wedge \operatorname{pears}^{\prime}(x)\right]$

(37) a. The soup warmed. (telic)

$\exists s \exists e\left[\operatorname{cool}^{\prime}(\operatorname{soup}, s, e) \wedge G O A L(\mathbf{c o o l}, s, e)\right]$

b. The soup warmed. (atelic)

$\exists s \exists g \exists e\left[w_{a r m}^{\prime}(\operatorname{soup}, s, e) \wedge G O A L(g, s, e)\right]$

${ }^{28}$ Marcel den Dikken (p.c.) points out that, in the presence of a quantized theme, particles like English up can also be argued to be responsible for the identification of the final subpart of the consumption scale. The particle is actually necessary when it comes to examples like ate the soup so that a telic interpretation can be guaranteed as these predicates are compatible with an atelic construal despite the quantized nature of the theme in them (see example (3a) in section 1). A similar claim can be found in Czardybon \& Fleischhauer $(2014,396)$ regarding the aspectual effect of auf in examples like Der Junge hat das Brot in fünf Minuten/(*fünf Minuten lang) aufgegessen 'The boy ate up the bread in five minutes/*for five minutes' in German. For more on quantized DPs allowing partitive readings and those that disallow such readings, see, for example, Piñón (2006). 
There are two aspectual contrasts in the representations above that need to be emphasized at this point. On the one hand, the predicate in (36a) is different from the example in (37a) in that the former supplies more information about the structure of the encoded scale than the latter, i.e., in (36a) the source point of the scale is uniquely determined given the verb-mediated relationship between the theme and scalar arguments. On the other hand, (36a) also contrasts with (37a) in that scalar boundedness in the case of the former is tied to the physical extent of the theme. In (36a), the upper bound or goal point on the scale can be determined given the spatial boundedness of the theme. This ultimately gives rise to telicity. Conversely, in (36b), the theme with cumulative reference does not ensure that the goal be uniquely determined, as shown by the variable $g$ indicating an unspecified goal in the logical representation, and thus the predicate receives an atelic reading. This correspondence between scale and theme does not characterize the examples in (37). In (37a), scalar boundedness arises due to context. This and the quantized nature of the theme give rise to a telic interpretation. In (37b), lack of contextual information as to a precisely determined goal yields atelicity. ${ }^{29}$

\section{Some consequences of the analysis for Hungarian}

In this section, I discuss further data from Hungarian, which follow from the scalar semantic analysis of the former sections. First, if the scalar structure that has been proposed for predicates expressing creation/consumption events above is along the right lines, it is expected that the (a)telicity facts of predicates expressing intellectual ingestion be in line with those of canonical creation/consumption predicates like eszik 'eat'. ${ }^{30}$ That is, an internal argument with quantized reference should be sufficient for calculating telicity, whereas cumulativity should give rise to atelicity. The data in (38) and (39) bear this out.

(38) a. János tíz perc alatt memorizált egy képlet-et.

J.NOM ten minute under memorized a formula-ACC

'János memorized a formula in ten minutes.'

${ }^{29}$ For more on the role of context in examples like (37a), see Kennedy \& Levin (2008).

30 That verbs like understand and learn form a grammatical class with verbs like eat and drink has also been shown with respect to Hindi in Masica (1976). In this language these verbs pattern together as they behave similarly under causativisation (see also Næss 2011). 
b. János tíz perc-ig/*tíz perc alatt képletek-et memorizált. J.NOM ten minute-for/ten minute under formulae-ACC memorized 'János memorized formulae for ten minutes.'

(39) a. Anna egy év alatt tanult tíz recept-et.

A.NOM a year under learned ten recipe-ACC

'Anna learned ten recipes in a year.'

b. Anna egy év-ig/*egy év alatt receptek-et tanult.

A.NOM a year-for/a year under recipes-ACC learned

'Anna learned recipes for a year.'

Second, activity verbs like fúr 'drill', which can express both creation and non-creation events, are also interpreted telically in the presence of a spatially bounded object on a creation construal. This is illustrated by fúr egy lukat 'drill a hole', but not by fúr egy falat lit. 'insert through a wall', which expresses a non-creation event (see also Kálmán 1995, 238-239). ${ }^{31}$

Likewise, just like durative dynamic predicates, achievements like tör 'break' and tép 'tear' can also describe either non-creation events or creation events. In the case of the former, the verb, whose event argument is associated with a mereologically simplex structure having exactly two proper parts, i.e., an initial and a final subpart, must occur with a particle (or a resultative expression) (cf. É. Kiss 2008, 21), as also discussed in section 3.3. Interestingly, when describing creation events, it is possible for these verbs to occur without a particle or a resultative phrase. In such cases, the verb and a quantized theme give rise to a telic interpretation. Consider (40) and (41), where (40) is from Peredy (2009), who also notes that the verb tör 'break' displays variable grammatical behavior depending on what theme argument it occurs with. ${ }^{32}$

31 That holes can behave like concrete objects in language has also been pointed out in Geuder $(2002,86)$.

${ }^{32}$ It has also been shown in the literature that different themes can be responsible for different creation events encoded in different ways in languages. Levinson (2007), for example, distinguishes between explicit creation as described by braid a necklace, where the DP in the verb phrase is the object of creation, and implicit creation as described by braid one's hair, where the created object is not named. That this distinction is grammatically relevant is supported by the fact that the explicit creation pattern is compatible with benefactive applicatives as in braided Mary a necklace, whereas the implicit creation pattern is not, as shown by the ungrammaticality of *braided Mary the strands (ibid., 116). 
(40) a. *(El)-törtem egy vázá-t. (non-creation pattern)

PRT-broke.I a vase-ACC

'I broke a vase.'

b. Törtem egy darab kenyer-et. (creation pattern)

broke.I a piece bread-ACC

'I broke a piece of bread (off of a loaf of bread).'

(adapted from Peredy 2009, 212, (25b) and (26b))

(41) a. Mari *(el)-tépett egy papírlap-ot. (non-creation pattern)

M.NOM (PRT)-tore a paper.sheet-ACC

'Mari tore a sheet of paper.'

b. Mari tépett egy darab papír-t. (creation pattern)

M.NOM tore a piece paper-ACC

'Mari tore off a piece of paper, thereby making this available for herself or someone else.'

(Kardos 2016, 25, (55))

Another set of the data that can be accounted for applying the scalar analysis of section 4 is one representing invariable atelicity, as in (42) and (43).

(42) Péter tíz perc-ig/*tíz perc alatt iszogatott egy limonádé-t.

P.NOM ten minute-for/ten minute under drank.small.sips a lemonade-ACC

'Péter drank small sips from a lemonade for 10 minutes.'

(43) Károly tíz perc-ig/*tíz perc alatt csipegetett egy csirkecomb-ot.

K.NOM ten minute-for/ten minute under ate.tiny.bites a chicken thigh-ACC

'Károly ate tiny bites from a chicken thigh for ten minutes.'

These predicates are unique, in that they receive a strictly atelic interpretation despite containing quantized themes, something that also characterizes English conatives like drank at a glass of beer. As proposed by Beavers (2010), this may be due to the fact that the predicate imposes a semantic constraint according to which the goal point on the scale be existentially bound. This, violating one of the conditions necessary for telicity to arise, yields invariable atelicity for the predicate. I propose that the data in (42) and (43) be analyzed along similar lines with the caveat that in Hungarian it is the frequentative morpheme -gat/-get that is responsible for the atelicizing effect. This claim is further strengthened by the data in (44) and (45), where -gat/-get is responsible for the derivation of strictly atelic iterative predicates. 
(44) Mari tíz perc-ig/*tíz perc alatt ütögette az asztal-t. M.NOM ten minute-for/ten minute under iterative hit the table-ACC 'Mari hit the table repeatedly for ten minutes.'

(45) János tíz perc-ig/*tíz perc alatt integetett.

J.NOM ten minute-for/ten minute under waved

'János waved for ten minutes.'

This property of -gat/-get has important consequences with other predicate classes as well. Specifically, if this morpheme has aspectual effects according to which the goal point associated with the scalar argument be existentially bound, verbs encoding two-point scales should be incompatible with it. This is borne out by the data in (46), where the achievement eltör 'break' proves to be quite unusual with the morpheme -get in examples like that in (43). For more examples of this sort, see Kiefer \& Ladányi $(2000,456)$ and Kiefer $(2006,164)$.
(46) "?Mari el-tör-ö-get-ett
egy vázá-t.

M.NOM PRT-break-linking vowel-FREQ-PAST.3SG a vase-ACC

As a reviewer points out, achievements like elad 'sell' are actually acceptable with the morpheme -gat/-get when they appear with a theme whose denotation can be partitioned and each cell corresponds to a different event. This also characterizes eltör 'break' as shown in (47).
a. Ákos el-ad-o-gat-ta
az ágyak-at.
Á.NOM PRT-give-linking vowel-FREQ-PAST.3SG the beds-ACC
'Ákos sold the beds, one bed at a time.'
b. Kati el-tör-ö-get-te a tányérok-at.
K.NOM PRT-break-linking vowel-FREQ-PAST.3SG the plates-ACC
'Kati broke the plates, one plate at a time.'

The expressions eladogatta az ágyakat 'sold the beds, one bed at a time' and eltörögette a tányérokat 'broke the plates, one plate at a time' are similar in that they express as many events as there are beds and plates, respectively. This construal is not possible in the presence of themes like egy ágy 'a bed' and egy tányér 'a plate', which denote singular entities. Thus, examples like (48) below sound odd:
(48) ?'Ákos el-ad-o-gat-ta
az ágy-at.
Á.NOM PRT-give-linking vowel-FREQ-PAST.3SG the bed-ACC 
Similar facts can be observed with other morphemes like -des and -ked, which are both frequentative suffixes.
(49) a. ?János el-tép-des-ett
egy vonatjegy-et.
J.NOM PRT-tear-FREQ-PAST.3SG a train ticket-ACC
a.' ?János el-tép-ked-ett egy vonatjegy-et.
J.NOM PRT-tear-FREQ-PAST.3SG a train ticket-ACC
b. János el-tép-des-te a vonatjegyek-et.
J.NOM PRT-tear-FREQ-PAST.3SG the train tickets-ACC
'János tore the train tickets into pieces, one ticket at a time.'
b.' János el-tép-ked-te a vonatjegyek-et.
J.NOM PRT-tear-FREQ-PAST.3SG the train tickets-ACC
'János tore the train tickets into pieces, one ticket at a time.'

As shown above, in the presence of a theme that denotes a singular entity, the verbs eltépdes 'tear into pieces, one piece at a time' and eltépked 'tear into pieces, one piece at a time' appear somewhat unnatural, as in (49a) and $\left(49 \mathrm{a}^{\prime}\right)$. However, once the theme denotes multiple entities, the sentence becomes fully grammatical, as in $(49 \mathrm{~b})$ and $\left(49 \mathrm{~b}^{\prime}\right) .{ }^{33}$

Another interesting question, raised by Marcel den Dikken (p.c.) concerning frequentative morphemes like those above, is where these elements are attached in the syntax. Based on their aspectual behavior, they are associated with the entire VP, but morphologically they appear directly on the verb. I leave this question for future work.

\section{Conclusion}

In this paper I have examined a variety of grammatical facts from the class of creation/consumption predicates and I have also devoted some attention to aspectual properties of non-creation/non-consumption predicates in Hungarian and in English. I hope to have shown that the scalar semantic analysis outlined in the paper can help us account for several aspectual

33 As expected, DE-verbs like érkezik 'arrive', which express punctual events, are generally incompatible with the frequentative morpheme -gat/-get, as shown by the ungrammaticality of examples like *János érkezgetett 'János was arriving'. However, in the environment of themes associated with a complex internal structure, the verb érkezget becomes acceptable as in Lassan érkezgettek a gólyák 'The storks were slowly arriving'. For more on iterative/frequentative morphemes in Hungarian, see, for example, Kiefer (2006; 2009). 
facts in these languages, including aspectual variability phenomena, which have received little attention so far, especially in Hungarian.

\section{Acknowledgments}

Special thanks are due to John Beavers and Gergely Pethő for the many useful discussions about creation/consumption verbs in English and Hungarian. I am also grateful to Marcel den Dikken and four anonymous reviewers for providing detailed and very helpful comments on an earlier version of this paper. All errors are my own responsibility.

\section{References}

Alberti, Gábor. 2004. Climbing for aspect: With no rucksack. In K. É. Kiss and H. van Riemsdijk (eds.) Verb clusters. A Study of Hungarian, German and Dutch. Amsterdam \& Philadelphia: John Benjamins. 253-289.

Bach, Emmnon. 1986. The algebra of events. Linguistics and Philosophy 9. 5-16.

Bach, Emmon. 1981. On time, tense, and aspect: An essay in English metaphysics. In P. Cole (ed.) Radical pragmatics. New York: Academic Press. 63-81.

Beavers, John. 2012. Lexical aspect and multiple incremental themes. In Demonte \& McNally $(2012,23-59)$.

Bende-Farkas, Ágnes. 1995. Prefixation and discourse. In Kenesei (1995, 192-220).

Bende-Farkas, Ágnes. 2002. Verb-object dependencies in Hungarian and English: A DRTbased account. Doctoral dissertation. Universität Stuttgart.

Bende-Farkas, Ágnes and Hans Kamp. 2001. Indefinities and binding. From specificity to incorporation. Lecture notes at ESSLLI 2001. University of Helsinki.

Borer, Hagit. 2005. Structuring sense: The normal course of events. Oxford: Oxford University Press.

Brinton, Laurel J. 1985. Verb particles in English: Aspect or aktionsart? Studia Linguistica 39. $157-168$.

Caudal, Patrick and David Nicolas. 2005. Types of degrees and types of event structures. In C. Maienborn and A. Wöllstein-Leisten (eds.) Event arguments in syntax, semantics and discourse. Tübingen: Niemeyer. 277-300.

Copley, Bridget and Heidi Harley. 2018. What would it take to tame the verbal hydra? Manuscript.

Csirmaz, Anikó. 2008a. Accusative case and aspect. In É. Kiss (2008a, 159-200).

Csirmaz, Anikó. 2008b. Igei argumentumszerkezet [The argument structure of the verb]. In Kiefer (2008, 185-228).

Csirmaz, Anikó. 2008c. Particles and a two component theory of aspect. In É. Kiss (2008a, 107-128).

Czardybon, Adrian and Jens Fleischhauer. 2014. Definiteness and perfectivity in telic incremental theme predications. In D. Gerland, C. Horn, A. Latrouite and A. Ortmann (eds.) Meaning and grammar of nouns and verbs. Düsseldorf: Düsseldorf University Press. 373-400. 
Dékány, Éva. 2008. El + verb complex predicates in Hungarian. Nordlyd Troms $\emptyset$ Working Papers on Language \& Linguistics 35. 1-17.

Demonte, V. and L. McNally (eds.). 2012. Telicity, change, and state: A cross-categorial view of event structure. Oxford: Oxford University Press.

Depreatere, Ilse. 1995. On the necessity of distinguishing between (un)boundedness and (a)telicity. Linguistics and Philosophy 18. 1-19.

Dowty, David R. 1979. Word meaning and Montague grammar: The semantics of verbs and times in generative syntax and in Montague's PTQ. Dordrecht: Reidel.

Dowty, David R. 1991. Thematic proto-roles and argument selection. Language 67. 547-619.

É. Kiss, Katalin. 1995. The definiteness effect revisited. In Kenesei (1995, 63-88).

É. Kiss, Katalin. 2002. The syntax of Hungarian. Cambridge: Cambridge University Press.

É. Kiss, Katalin. 2005. First steps towards a theory of the verbal particle. In C. Piñón and P. Siptár (eds.) Approaches to Hungarian 9: Papers from the Düsseldorf conference. Budapest: Akadémiai Kiadó. 57-88.

É. Kiss, Katalin (ed.). 2008a. Event structure and the left periphery. Studies on Hungarian (Studies in natural language \& linguistic theory 68). Dordrecht: Springer.

É. Kiss, Katalin. 2008b. The function and the syntax of the verbal particle. In É. Kiss (2008a, 16-55).

É. Kiss, Katalin (ed.). 2009. Adverbs and adverbial adjuncts at the interfaces (Interface explorations 20). Berlin \& New York: Mouton de Gruyter.

Farkas, Imola-Ágnes and Éva Kardos. 2018. Non-maximal event delimitation in Hungarian. Argumentum 14. 368-382.

Farkas, Imola-Ágnes and Éva Kardos. 2019. A végpontosság mint szituációs aspektuális jegy jelölése a magyar nyelvben. 1. rész [Marking telicity as a situation aspectual property in Hungarian. Part 1]. Magyar Nyelv 115. 176-185.

Farkas, Imola-Ágnes and Éva Kardos. in press. A végpontosság mint szituációs aspektuális jegy jelölése a magyar nyelvben. 2. rész [Marking telicity as a situation aspectual property in Hungarian. Part 2]. Magyar Nyelv 115.

Filip, Hana. 1999. Aspect, eventuality types and nominal reference. New York: Garland.

Filip, Hana. 2008. Events and maximalizatio. In S. Rothstein (ed.) Theoretical and crosslinguistic approaches to the semantics of aspects. Amsterdam \& Philadelphia: John Benjamins. 217-256.

Filip, Hana and Susan Rothstein. 2006. Telicity as a semantic parameter. In J. Lavine, S. Franks, M. Tasseva-Kurktchieva and H. Filip (eds.) Formal approaches to Slavic linguistics 14: The Princeton meeting. Ann Arbor, MI: Michigan Slavic Publications. $139-156$.

Fleischhauer, Jens and Adrian Czardybon. 2016. The role of verbal prefixes and particles in aspectual composition. Studies in Language 40. 176-203.

Geuder, Wilhelm. 2002. Oriented adverbs: Issues in the lexical semantics of event adverbs. Doctoral dissertation. Universität Tübingen.

Gruber, Jeff. 1965. Studies in lexical relations. Doctoral dissertation. MIT. Published as Lexical Structures in Syntax and Semantics. North Holland, Amsterdam, 1976.

Hay, Jennifer, Christopher Kennedy and Beth Levin. 1999. Scalar structure underlies telicity in 'Degree Achievements'. In T. Matthews and D. Strolovitch (eds.) Semantics 
and linguistic theory (SALT) IX. Ithaca, NY: CLC Publications, Cornell University. 127-44.

Jackendoff, Ray. 1983. Semantics and cognition. Cambridge, MA: MIT Press.

Jackendoff, Ray. 1990. Semantic structures. Cambridge, MA: MIT Press.

Jackendoff, Ray. 1996. The proper treatment of measuring out, telicity, and perhaps even quantification in English. Natural Language and Linguistic Theory 14. 305-354.

Kálmán, László. 1995. Definiteness effect verbs in Hungarian. In Kenesei (1995, 221-242).

Kardos, Éva. 2012. Toward a scalar semantic analysis of telicity in Hungarian. Doctoral dissertation. University of Debrecen.

Kardos, Éva. 2016. Telicity marking in Hungarian. Glossa 1. 41.

Kenesei, István (ed.). 1995. Approaches to Hungarian 5: Levels and structures. Szeged: JATEPress.

Kennedy, Christopher. 2012. The composition of incremental change. In Demonte \& McNally $(2012,103-121)$.

Kennedy, Christopher and Beth Levin. 2008. Measure of change: The adjectival core of degree achievements. In Adjectives and adverbs: Syntax, semantics, and discourse. Oxford: Oxford University Press. 156-182.

Kennedy, Christopher and Louise McNally. 2005. Scale structure, degree modification, and the semantics of gradable predicates. Language 81. 345-381.

Kiefer, Ferenc. 1992. Az aspektus és a mondat szerkezete. In F. Kiefer (ed.) Strukturális magyar nyelvtan 1. Mondattan. Budapest: Akadémiai Kiadó. 797-886.

Kiefer, Ferenc. 2006. Aspektus és akcióminôség, különös tekintettel a magyar nyelvre [Aspect and Aktionsart - with special reference to Hungarian]. Budapest: Akadémiai Kiadó.

Kiefer, Ferenc (ed.). 2008. Strukturális magyar nyelvtan 4. A szótár szerkezete [A structural grammar of Hungarian 4. The structure of the lexicon]. Budapest: Akadémiai Kiadó.

Kiefer, Ferenc. 2009. Types of temporal adverbials and the fine structure of events. In É. Kiss $(2009,247-267)$.

Kiefer, Ferenc and Mária Ladányi. 2000. Az igekötők [Verbal particles]. In F. Kiefer (ed.) Strukturális magyar nyelvtan 3. Morfológia [A structural grammar of Hungarian 3. Morphology]. Budapest: Akadémiai Kiadó. 453-518.

Krifka, Manfred. 1989. Nominal reference, temporal constitution and quantification in event semantics. In R. Bartsch, J. van Benthem and P. van Emde Boas (eds.) Semantics and contextual expression. Dordrecht: Foris. 75-115.

Krifka, Manfred. 1992. Thematic relations as links between nominal reference and temporal constitution. In I. A. Sag and A. Szabolcsi (eds.) Lexical matters: From cognitive structures to syntactic structures. Stanford, CA: CSLI Publications. 29-53.

Krifka, Manfred. 1998. The origins of telicity. In S. Rothstein (ed.) Events and grammar. Dordrecht: Kluwer. 187-235.

Levin, Beth. 2010. Lexicalized scales and verbs of scalar change. Paper presented at CLS 46, Chicago Linguistic Society, Chicago, IL.

Levin, Beth and Peter Sells. 2009. Unpredicated particles. In L. H. Wee and L. Uyechi (eds.) Reality exploration and discovery: Pattern interaction in language and life. Stanford, CA: CSLI Publications. 303-324. 
Levinson, Lisa. 2007. The roots of verbs. Doctoral dissertation. New York University.

Maleczki, Márta. 1995. On the definiteness effect in Hungarian. A semantic approach. In Kenesei (1995, 261-286).

Maleczki, Márta. 2008. Határozatlan argumentumok [Indefinite arguments]. In Kiefer (2008, 129-184).

Masica, Colin P. 1976. Defining a linguistic area: South Asia. Chicago: The University of Chicago Press.

Milsark, Gary L. 1977. Toward an explanation of certain peculiarities of the existential construction in English. Linguistic Analysis 3. 1-29.

Moens, Marc and Mark Steedman. 1988. Temporal ontology and temporal reference. Computational Linguistics 14. 15-29.

Mourelatos, Alexander P. D. 1978. Events, processes, and states. Linguistics and Philosophy 2. 415-434.

Mourelatos, Alexander P. D. 1981. Events, processes, and states. In P. J. Tedeschi and A. Zaenen (eds.) Tense and aspect (Syntax and Semantics 14). New York: Academic Press. 191-212.

Næss, Åshild. 2011. The grammar of eating and drinking verbs. Language and Linguistics Compass 5. 413-423.

Peredy, Márta. 2009. Obligatory adjuncts licensing definiteness effect constructions. In É. Kiss $(2009,197-230)$.

Piñón, Christopher. 1995. Around the progressive in Hungarian. In Kenesei (1995, 153-90).

Piñón, Christopher. 2006. A problem of aspectual composition. Manuscript.

Piñón, Christopher. 2008. Weak and strong accomplishments. In É. Kiss (2008a, 91-106).

Ramchand, Gillian. 2008. Verb meaning and the lexicon: A first phase syntax. Cambridge: Cambridge University Press.

Rappaport Hovav, Malka. 2008. Lexicalized meaning and the internal temporal structure of events. In S. Rothstein (ed.) Theoretical and crosslinguistic approaches to the semantics of aspect. Amsterdam \& Philadelphia: John Benjamins. 13-43.

Rappaport Hovav, Malka and Beth Levin. 2010. Reflections on manner/result complementarity. In M. Rappaport Hovav, E. Doron and I. Sichel (eds.) Lexical semantics, syntax, and event structure. Oxford: Oxford University Press. 21-38.

Rothstein, Susan. 2006. Telicity at the dinner table: Do I have to eat it all? In H.-M. Gärtner, S. Beck, R. Eckardt, R. Musan and B. Stiebels (eds.) Between 40 and 60 puzzles for Krifka. Berlin: Leibniz-Zentrum Allgemeine Sprachwissenschaft (ZAS).

Smith, Carlota S. 1991. The parameter of aspect. Dordrecht: Kluwer.

Smollett, Rebecca. 2005. Quantized direct objects don't delimit after all. In H. J. Verkuyl, H. de Swart and A. van Hout (eds.) Perspectives on aspect. Dordrecht: Springer. $41-59$.

Stechow, Arnim von. 2001. Temporally opaque arguements in verbs of creation. In B. Cecchetto, G. Chierchia and M. T. Guasti (eds.) Semantic interfaces: Reference, anaphora, aspect. Stanford, CA: CSLI. 278-319.

Swart, Henriëtte de. 1998. Aspect shift and coercion. Natural Language and Linguistic Theory 16. 347-85. 
Szabolcsi, Anna. 1986. From the definiteness effect to lexical integrity. In W. Abraham and S. de Meij (eds.) Topic, focus, and configurationality. Amsterdam \& Philadelphia: John Benjamins. 321-348.

Tenny, Carol L. 1994. Aspectual roles and the syntax-semantics interface. (Studies in Linguistics and Philosophy 52). Dordrecht: Kluwer.

Travis, Lisa. 2010. Inner aspect. Dordrecht: Springer.

Verkuyl, Henk J. 1972. On the compositional nature of the aspects. Dordrecht: Reidel.

Verkuyl, Henk J. 1993. A theory of aspectuality: The interaction between temporal and atemporal structure (Cambridge Studies in Linguistics, Vol. 64). Cambridge: Cambridge University Press.

Verkuyl, Henk J. and Joost Zwarts. 1992. Time and space in conceptual and logical semantics: The notion of path. Linguistics 30. 483-511.

Wacha, Balázs. 1978. Az igés-szerkezeti aspektus kategóriája a magyar nyelvben [The verbal aspectual category in Hungarian]. Bölcsészdoktori értekezés. ELTE, Budapest.

Wechsler, Stephen. 2005. Resultatives under the 'event-argument homomorphism' model of telicity. In N. Erteschik-Shir and T. Rapoport (eds.) The syntax of aspect. Oxford: Oxford University Press. 255-273.

Open Access. This is an open-access article distributed under the terms of the Creative Commons Attribution 4.0 International License (https://creativecommons.org/licenses/ by/4.0), which permits unrestricted use, distribution, and reproduction in any medium, provided the original author and source are credited, a link to the CC License is provided, and changes - if any - are indicated. (SID_1) 
